\title{
Strategy Competitive Advantages through Marketing Performance
}

\author{
${ }^{1}$ Nurul Rizka Arumsari, ${ }^{2}$ Mira Meilia Marka \\ ${ }^{1,2}$ Department of Management, Faculty of Economics and Business, \\ Muria Kudus University \\ Email: nurul.rizka@umk.ac.id
}

\section{Abstract}

This study aims to describe efforts to create competitive advantages through marketing performance based on product innovation and promotion on SMEs weaving Troso in Jepara district. The research method used is multiple linear regression analysis 2 stages with sampling technique using purposive sampling. The results showed that product innovation as measured by three indicators covering product line, new product, and artificial product have a positive and significant influence on marketing performance. Promotions measured by six indicators covering advertising, personal selling, sales promotion and publicity have proven to have a positive and significant impact on marketing performance. Marketing performance measured by three indicators that include profit targets, customer growth, and sales turnover have a positive and significant impact on competitive advantage.

Keywords: competitive advantage, marketing performance, product innovation, promotion

JEL $\quad:$ M31

DOI $\quad: 10.24002 /$ kinerja.v22i2.1812

Received : 13-09-2018 Reviewed: 01-10-2018 Final Version: 04-10-2018

\section{INTRODUCTION}

Competition is very important for the success or excellence of the company. The increasing number of SMEs today leads to the sustainability of businesses facing rapid competition, especially the industry of similar products makers. Therefore a company must have a strategy that is designed to realize competitive advantage (Wulandari, 2012). Marketing performance is an exposition used in measuring the impact of the company's strategy and targets. Marketing strategy is always aimed to realize maximum marketing performance such as sales quantity and sales growth rate (Ismawanti, 2008). The village of Troso Pecangaan is the 
center of weaving craft and is the second superior product of Jepara regency after the furniture industry and carving. The Troso buckle woven fabric is woven from the strands of the weft thread or the warp thread previously tied and immersed in a natural dye. Tied fabrics can be sewn to be used as clothing, furniture upholstery, or home interior decorator. From the side of history, craft woven Troso Jepara into one of the hereditary efforts.

According to local residents, weaving troso ikat since the entry of Islam in the village of Troso i.e during the Islamic Mataram kingdom. In the beginning this woven fabric was made only for the complementary needs of clothing only, and to meet the distinguished scholars who were spreading Islam in the village of Troso. The skill of making Troso weaving was already owned by the villagers of Troso long before the independence of Indonesia which was around 1935. The beginning of the troso made weaving Gedong, then in 1943 expertise developed by making Pancal Weaving. If seen, weaving Troso Jepara has a distinctive design that until now still maintained the ethnic motifs nuanced, traditional, classical and unique. Nevertheless, the troso ikat weaving is not left behind with modern contemporary motifs. So far, the production of Troso fabrics has produced woven fabrics with various motifs such as misris motifs, krisna, motifs carving, motif chains, rose motifs, bamboo motifs, bird motifs, dragon motifs, wax motifs, antique motifs, motifs cempaka, motif dewi sri, motif amethyst, motif of SBY, motif obama and others. Marketing performance on SMEs weaving Troso Jepara that became one of the focus of government attention Jepara expected to always increase. However this has not been able to provide significant progress on the condition of SMEs. With the publication of regulations of the domestic government No. 68 of 2015 on the regulation of uniforms for the State Civil Apparatus or ASN formerly called civil servants that the use of regional uniforms of service is only allowed on Friday. Before the rule was issued, ASN in Jepara wore a typical regional service uniform for four days. Tuesday to Friday, ASN Jepara wearing Troso. Since the rule of the government came out, the sales of Troso dropped dramatically. So that causes many craftsmen bankrupt. The number of Troso Jepara weaving has decreased from 2014 to 2016 shown in the following data:

Table 1. Number of SMEs Weaving Troso

\begin{tabular}{lllll}
\hline SMEs & & 2014 & 2015 & 2016 \\
\hline Waeving Troso & Unit & 698 & 517 & 228
\end{tabular}

Source: Jepara in number 2016

The bankrupt craftsmen are small category who use non-machine or ATBM looms. Most entrepreneurs can not compete which is processed by machine. With the use of these machines entrepreneurs can produce weaving faster with the selling price of affordable products. The condition is also influenced by the diversity 
of ikat products. The design of weaving products that have been developed is limited to monotonous motives. The less varied designs show low innovation capability, Innovation is necessary in supporting marketing performance. Innovation can be done through variations of motifs, materials or manufacturing techniques. Customers generally want innovative products to suit their needs and tastes. The success of innovation development is a step forward among its competitors. This condition requires industry sector actors to more closely recognize the character and taste of their target market so that the development of innovation can meet the needs and desires of consumers. Therefore, the development of product innovation must be designed and executed appropriately. (Suhendro, 2010). The larger the network size, the wider important information related to the enterprises; therefore, it will increase opportunity to innovate (Mursid, et al 2018). Promotion is one aspect determinant of success of a marketing program to share information about the existence of product (Fandy Tjiptono, 2008). The activity of persuading consumers can be done to encourage buyers to shop, right now with a particular brand choice. Business actors in managing ikat are still low in increasing their target market through promotion. Troso Jepara weaving is known only for office uniforms. This is one obstacle why Troso Jepara weaving is not known to the general public. Only the people of Jepara and surrounding cities are familiar with Troso weaving knots. From the description looks about the importance of product innovation and promotion needed in improving the performance of marketing SMEs weaving Troso Jepara.

The formulation of the problem in this research is how to increase the number of consumers to improve marketing performance through product innovation and promotion to create competitive advantage on umkm ikat troso Jepara. The limitation of this research is to analyze the effect of product innovation and promotion on marketing performance and strategy to create competitive advantage.

\section{LITERATURE REVIEW}

\subsection{Marketing}

According to Kotler and Armstrong (2008) marketing is defined as "the process by which companies create value for customers and build strong relationships with customers, with the aim of capturing the value of the customer in return". From the meaning above, it can be seen that marketing is a series of bases in targeting the target market, discussing customer needs, developing goods and services, satisfying needs, providing value to customers and profits for the company. 


\subsection{Product Innovation}

The product is an entity that is offered as an effort to reach the company's target, through meeting the needs and desires of consumers. The opinion of Kotler and Keller (2012) states that: "Products are anything that can be offered to the market to satisfy desires or needs".

Innovation is one of the determinant aspects of company success needed to survive. The company must make a breakthrough in meeting the needs of potential consumers, participate in new exploration, contribute to new ideas, analyze and simulate productively. All of them are efforts to produce actual products, technology services / processes, technological changes and existing practices (Liu et.al, 2011). Product innovation consists of product expansion activities, product improvement, development to increase the number of product lines that the company can offer. Successful innovation is simple and focused, must be clearly planned and has a strategy that can be applied. Factors affecting the ability of product innovation according to (Martinez et al, 2011) there are three, namely factors of knowledge, organization and human factors.

Suhendro (2010) conducted a research on effect of Product innovation through marketing performance to achieve sustainable competitive advantage (Case study in the Small and Medium Industries of Pekalongan Batik). The results show that product innovation can improved with increase customer orientation, competitor's orientation and cross coordination function. Furthermore, product innovation the higher will be affect performance next marketing. Analytical tool with Structural Equation Modem.

\subsection{Promotion}

Promotion is an activity to introduce products to customers and influence them to be interested in buying. Promotion is one of the determinant aspects of the success of a marketing program to provide information about the existence of a product (Fandy Tjiptono, 2008). In general, forms of promotion have the same function, but these forms are distinguished based on specific tasks. Some special tasks are called promotion mix (Fandy Tjiptono, 2008: 222).

Wartini (2012) conducted a research on influence analysis promotion, price and product excellence towards performance marketing. Research result by using empirical data show that promotion variable, price and excellence proven product have influence positive and significant to marketing performance. Analytical tool with Regression Multiple and Coefficient Determination. 


\subsection{Marketing Performance}

Marketing performance can be seen as a design to test the extent to which market performance has been achieved by the products produced by the company (Fernando, 2016). Marketing strategy is always aimed at realizing maximum marketing performance such as sales quantity and sales growth rate (Ismawanti, 2008). Measures of marketing performance are Target Profit, Customer Growth and Sales Turnover. Performance is a system related to activities with results obtained. Improving marketing performance of SMEs is basically a marketing alliance (joint marketing) of a number of coordinated SMEs in partnership. Measures of marketing performance can be seen from 1) Target of Profit, 2) Customer Growth, and 3) Sales Turnover. (Widjajanti, 2012). Important aspects excel in competition is by providing customer value and satisfaction through the presentation of valuable products and services at competitive prices (Tjiptono, 2008).

\subsection{Competitive Advantage}

Competitive advantage can be achieved if a company is able to provide a higher customer value than competitors (Fatonah, 2009). The main key in winning the competition is by providing value and satisfaction to customers through the delivery of quality products and services at competitive prices (Tjiptono, 2008). Competitive marketing strategies are strategies that position the company strongly in the face of competitors and provide the strongest strategic advantage for the company (Kotler, 2010).

Numerous empirical studies have evaluated the relationship between marketing performance and strategy of competitive advantage. Dewanti et.,al., (2010) conducted a research on role orientation market, program promotion and innovation in deciding marketing performance. The study found that market orientation partial effect significant improve the performance credit marketing services. Promotion program partially significant effect towards performance marketing, so too economic innovation have been done managed to influence on performance marketing. Analytical tool with regression correlation.

Wulandari (2012) conducted a research on Effect of Orientation Customer, Orientation Competitors and Innovations Product against Marketing Performance. The study found that The higher it is customer orientation, competitor's orientation and product innovation then marketing performance will get more increase. Analytical tool with Regression Linear Double. 
Sutrisno and Suryawardana (2014) conducted a research on Effect Of product, innovation, promotion, consumer behavior and the quality of performance marketing through the power seller interverning variables motors products Japanese in town Semarang. The study found that influential promotion significantly towards performance marketing. this matter evidenced from the results partial effect test obtained by $22.9 \%$. The promotion deep inside company is basic needs which in turn will be able to create opportunities sales. Promotion able to push sales and improve the performance marketing. Analytical tool with Regression Linear.

From the literature review shows that marketing performance through product innovation and promotion can increase the growth of SMEs. Improving marketing performance of SMEs is basically a marketing alliance (joint marketing) of a number of coordinated SMEs in partnership

\section{RESEARCH METHOD}

The object of this research is SMEs Troso which is located in Jepara regency, Central Java, Indonesia. Methods in this study with pre-survey, observation and literature study that aims to determine the impact of product innovation and promotion to improve marketing performance and create competitive advantage. Method of collecting data by interview, document record. Data collection tool using questionnaire which aims to get answers to research questions. The sample in this research is Troso weavers who have uniqueness that is needed in research. The determination of representative samples depends on the number of indicators multiplied by 5 to 10 (Hair et al, 2010). Sample selection in this research is using Purposive Sampling with criterion: craftsman still using non-machine loom (ATBM); craftsmen who have not yet used web-based promotional media. The method of data analysis with multiple linear regression of two stages with statistial package for the social scienes program which aims to obtain empirical evidence of the impact of product innovation and promise to improve marketing performance and create competitive advantage. In this research, there are two types of variables observed and will be measured. These variables include independent variables (product innovation, promotion) and dependent variable (marketing performance and competitive advantage). Here are some indicators used in this study.

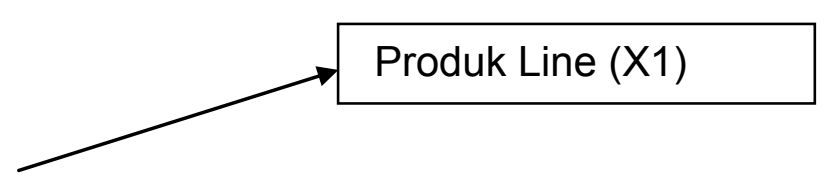




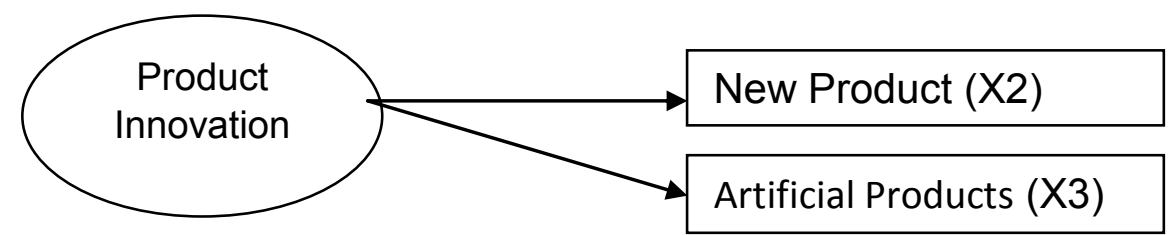

Figure 1. Variable Product Innovation and Measurement Indicators

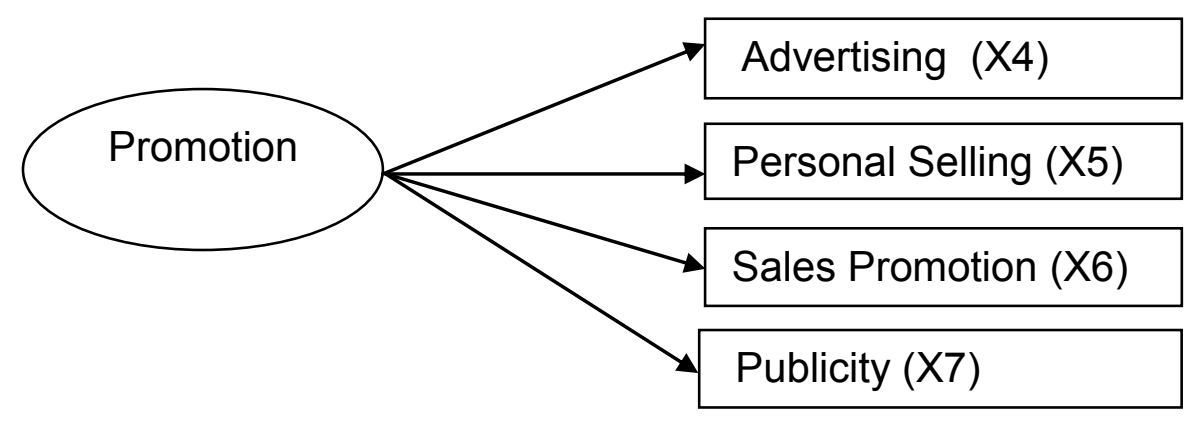

Figure 2. Variable Promotion and Measurement Indicators

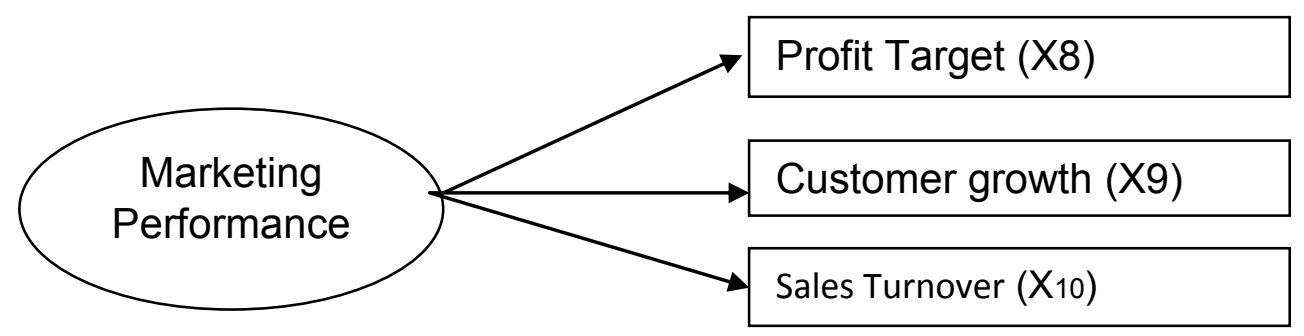

Figure 3. Variable Marketing Performance and Measurement Indicators

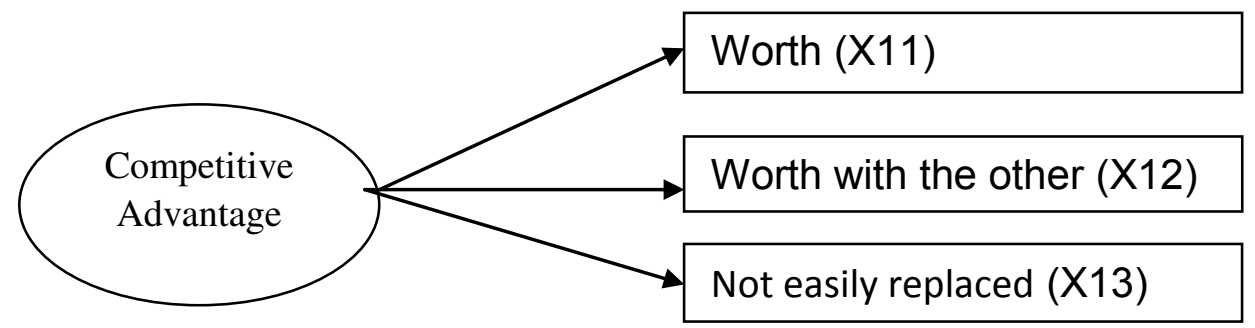

Figure 4. Variable Competitive Advantage and Measurement Indicators 


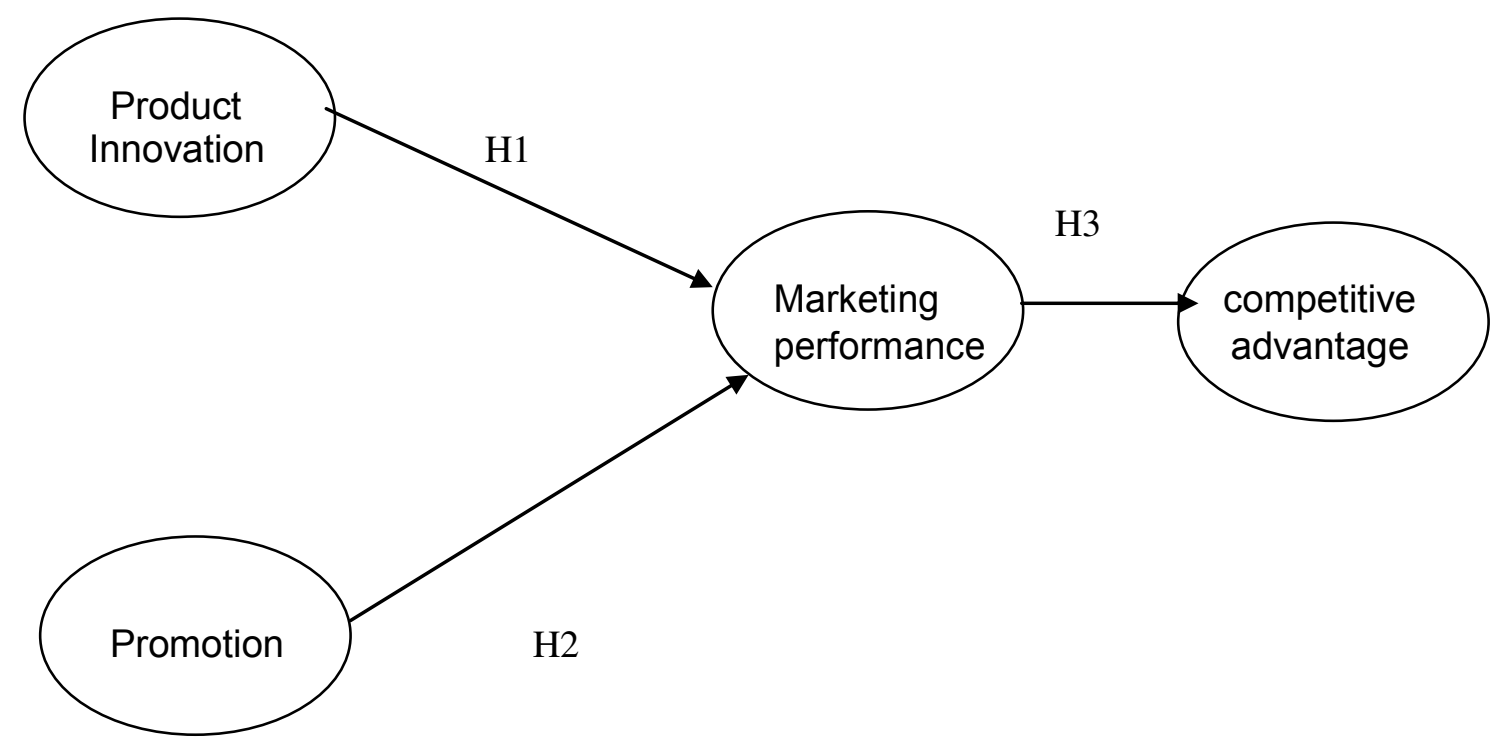

Figure 5. research model

\section{DISCUSSION OF THE RESULT}

The number of respondents in this study amounted to 65 respondents. The majority of respondents male gender of 83.1 percent and the remaining 16.9 percent female sex. The age of respondents between 20-65 years.

After the questionnaire is distributed to the respondent, the next step is testing the instrument using validity test and reliability test. Validity test is used to measure the validity or validity of a questionnaire. A questionnaire is said to be valid if the questionnaire statement is able to reveal something that will be measured by the questionnaire. The basis of the decision to test the validity of the indicator is:

a. If $r$ count is positive and $r$ count $>r$ table then the item or variable is valid. b. If $\mathrm{r}$ arithmetic is not positive and $\mathrm{r}$ arithmetic $<\mathrm{r}$ table then the item or variable is not valid. To test the validity of the questionnaire required validity and reliability tests with the help of SPSS version 20 then obtained the following results:

Table 2. Product Innovation Validity Test

\begin{tabular}{lllll}
\hline No & Indicator & $\mathbf{r}$ value & Sig & Results \\
\hline
\end{tabular}




\begin{tabular}{lllll}
\hline $\mathbf{1}$ & $\mathrm{X} 11$ & 0,886 & 0,000 & Valid \\
$\mathbf{2}$ & $\mathrm{X} 12$ & 0,907 & 0,000 & Valid \\
$\mathbf{3}$ & $\mathrm{X} 13$ & 0,746 & 0,000 & Valid \\
\hline
\end{tabular}

Source: proceed data, 2018

Referring to table 2 above, the value of $r$ is greater than $r$ table. In this study $r$ table is known as 0.3. In quick look, the value of significance is below 0.05 so this indicates that all indicators in this variable are valid and can proceed to the next process. Quickly the output results interpret that with a significance value of 0.000 for all indicators are valid. Reinforced by calculating the correlation value greater than $r$ table then further strengthens the argument that the four indicators can represent the promotion variable. In this study $r$ table is known as 0.3 .

Table 3. Promotion Validity Test

\begin{tabular}{ccccc}
\hline No & Indicator & r value & Sig & Results \\
\hline $\mathbf{1}$ & X21 & 0,441 & 0,000 & Valid \\
$\mathbf{2}$ & X22 & 0,794 & 0,000 & Valid \\
$\mathbf{3}$ & X23 & 0,760 & 0,000 & Valid \\
$\mathbf{4}$ & X24 & 0,788 & 0,000 & Valid \\
\hline
\end{tabular}

Source: proceed data, 2018

The marketing performance variable that is an independent variable is represented through three indicators. The results obtained calculation that each variable has a significance value of 0.000 where it gives meaning that the lack of 0.05 then the indicator is valid. In this study $r$ table is known as 0.3.

Table 4. Marketing Perfomance Valildity Test

\begin{tabular}{lllll}
\hline No & Indicator & r value & Sig & Results \\
\hline $\mathbf{1}$ & Y11 & 0,761 & 0,000 & Valid \\
$\mathbf{2}$ & Y12 & 0,678 & 0,000 & Valid \\
$\mathbf{3}$ & Y13 & 0,687 & 0,000 & Valid \\
\hline
\end{tabular}


Source: proceed data, 2018

The variables of competitive advantage which are independent variables are represented through three indicators. The results obtained calculation that each variable has a significance value of 0.000 where it gives meaning that the lack of 0.05 then the indicator is valid. In this study $\mathrm{r}$ table is known as 0.3 .

Table 5. Competitive Advantage Test

\begin{tabular}{ccccc}
\hline No & Indicator & r value & Sig & Results \\
\hline $\mathbf{1}$ & Y21 & 0,708 & 0,000 & Valid \\
$\mathbf{2}$ & Y22 & 0,848 & 0,000 & Valid \\
$\mathbf{3}$ & Y23 & 0,663 & 0,000 & Valid \\
\hline
\end{tabular}

Source: proceed data, 2018

Reliability test is a tool to measure a questionnaire which is an indicator of the variable. A construct or variable is said to be reliable if Cronbach Alpha value> 0.60 then the variable item is declared reliable. The table below is a summary of the reliability test for each independent variable and the dependent variable. Obtained test results that all variables in this study have reliability (reliable).

Table 6. Reliability Test

\begin{tabular}{clc}
\hline No & \multicolumn{1}{c}{ Variabel } & Cronbach's Alpha \\
\hline $\mathbf{1}$ & Inovasi Produk & 0,845 \\
$\mathbf{2}$ & Promosi & 0,781 \\
$\mathbf{3}$ & Kinerja Pemasaran & 0,779 \\
$\mathbf{4}$ & Keunggulan Bersaing & 0,774 \\
\hline
\end{tabular}

Source: proceed data, 2018

Hypothesis testing in this study used two-step regression analysis. The value of the determination coefficient on the regression phase was obtained $\left(R^{2}\right)$ of 0.491 . The marketing performance variables that can be explained by product innovation and promotion is $49.1 \%$ and the remaining $50.1 \%$ is influenced by other factors.

Table 7. $t$ Test 
Model Summary

\begin{tabular}{|c|c|c|c|c|}
\hline Model & $\mathrm{R}$ & $\begin{array}{c}\mathrm{R} \\
\text { Sauare }\end{array}$ & Adjusted R & Std. Error of the Estimate \\
\hline 1 &, $712^{\mathrm{a}}$ & ,507 & ,491 & 831 \\
\hline
\end{tabular}

a. Predictors: (Constant), promotion, product innovation

Source: proceed data, 2018

ANOVA test obtained result that is 31.928 with probability 0.000 . This means product innovation and promotion together have an influence on marketing performance.

Table 8. f Test

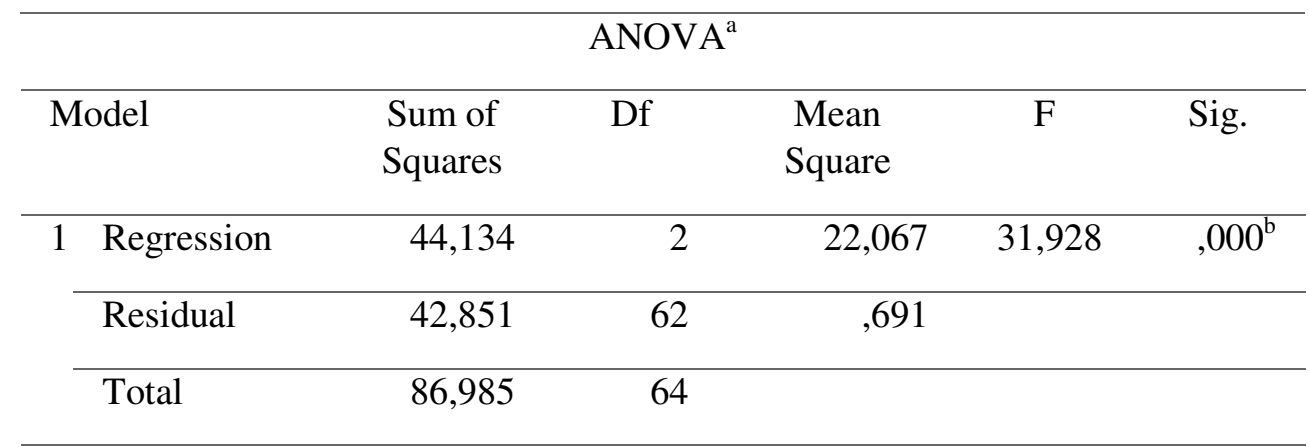

a. Dependent Variable: marketing performance

b. Predictors: (Constant), promotion, product innovation

Source: proceed data, 2018

Result of $t$ test to independent variable obtained probability value less than 0,05 , for product innovation variable $t$ value equal to 3,292 and probability value 0,002 . The results of this study provide empirical evidence that product innovation variables have an influence on marketing performance variables, proven. This is in accordance with the opinion said by Wulandari (2012) that if it can create product innovation will determine the performance of marketing in accordance with corporate goals. The higher the product innovation the better the marketing performance. The second hypothesis of promotion has influence on marketing performance of SMEs weaving Troso Jepara with $t$ test result that is 4,705 and probability value 0.000 . Promotion is one of the determinants of the success of marketing programs to provide information about the existence of product sutu (Tjiptono, 2008). The higher the promotion the company performs the better the marketing performance. 
Table 9. SPSS Calculation Result of Phase 1

\begin{tabular}{|c|c|c|c|c|c|c|}
\hline \multicolumn{7}{|c|}{ Coefficients $^{\mathrm{a}}$} \\
\hline \multicolumn{2}{|c|}{ Model } & \multicolumn{2}{|c|}{$\begin{array}{l}\text { Unstandardized } \\
\text { Coefficients }\end{array}$} & \multirow{2}{*}{$\begin{array}{c}\text { Standardized } \\
\text { Coefficients } \\
\text { Beta }\end{array}$} & \multirow[t]{2}{*}{$\mathrm{t}$} & \multirow[t]{2}{*}{ Sig. } \\
\hline & & B & $\begin{array}{l}\text { Std. } \\
\text { Error }\end{array}$ & & & \\
\hline \multirow[t]{3}{*}{1} & (Constant & 6,441 & ,997 & & 6,463 & ,000 \\
\hline & $\begin{array}{l}\text { Product } \\
\text { innovatio } \\
n\end{array}$ & ,262 & ,080 & ,338 & 3,292 & ,002 \\
\hline & $\begin{array}{l}\text { Promotio } \\
\mathrm{n}\end{array}$ & ,256 & ,054 & ,482 & 4,705 & ,000 \\
\hline
\end{tabular}

a. Dependent Variable: marketing performance

Source: proceed data, 2018

The second regression hypothesis test obtained the coefficient of determination $\mathrm{R}^{2}=0.445$. Variable of competitive advantage can be explained by marketing performance variable equal to $44,5 \%$ while the rest $55,5 \%$ influenced by other factor.

Table 10. $t$ test second regression

\section{Model Summary}




\begin{tabular}{rrrrr}
\hline Model & $\mathrm{R}$ & $\begin{array}{c}\mathrm{R} \\
\text { Square }\end{array}$ & $\begin{array}{c}\text { Adjusted R } \\
\text { Square }\end{array}$ & $\begin{array}{r}\text { Std. Error of } \\
\text { the Estimate }\end{array}$ \\
\hline 1 &, $673^{\mathrm{a}}$ &, 453 &, 445 &, 942
\end{tabular}

a. Predictors: (Constant), marketing performance

Source: proceed data, 2018

ANOVA test obtained result that is 52.223 with probability 0.000 . Probability is less than 0.05 , it can be said that marketing performance has an effect on competitive advantage.

Table 11. f Test second regression

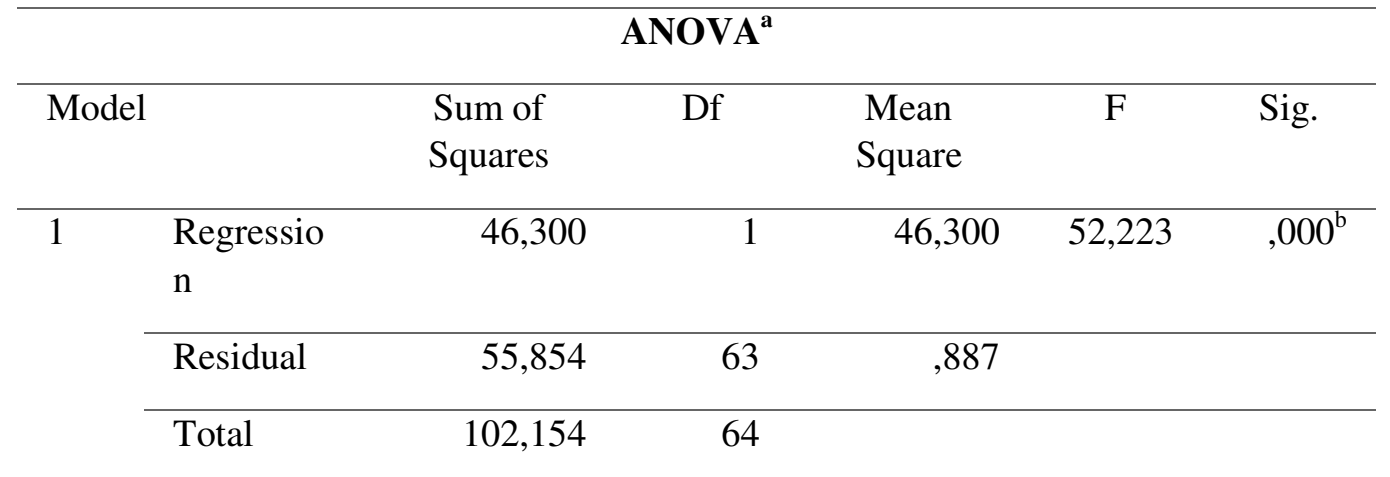

a. Dependent Variable: competitive advantage

b. Predictors: (Constant), marketing performance

Source: proceed data, 2018

In the calculation results of regression phase 2 obtained $\mathrm{Y} 2=0.673 \mathrm{Y} 1$. The performance of SME marketing Troso Jepara weaving has an influence on the competitive advantage with regression coefficient of 0.673 .

Table 12. SPSS Calculation Result of Phase 2

\begin{tabular}{|c|c|c|c|c|c|}
\hline \multicolumn{6}{|c|}{ Coefficients $^{a}$} \\
\hline \multirow[t]{2}{*}{ Model } & $\begin{array}{r}\text { Uns } \\
\mathrm{C}\end{array}$ & $\begin{array}{l}\text { ardized } \\
\text { ients }\end{array}$ & $\begin{array}{l}\text { Standard } \\
\text { ized } \\
\text { Coefficie } \\
\text { nts }\end{array}$ & $t$ & Sig. \\
\hline & $B$ & $\begin{array}{l}\text { Std. } \\
\text { Error }\end{array}$ & Beta & & \\
\hline
\end{tabular}




\begin{tabular}{llrrrrr}
\hline 1 & (Constant) & 3,40 & 1,397 & & 2,4 &, 01 \\
& 5 & & 38 & 8 \\
\cline { 2 - 6 } & Marketing &, 730 &, 101 &, 673 & 7,2 &, 00 \\
& performance & & & & 27 & 0
\end{tabular}

a. Dependent Variable: competitive advantage

Source: proceed data, 2018

On the hypothesis of marketing performance variables affect the benefits of competing with the results of $t$ test is 7.227 and the probability value 0.000 . Based on the results of these studies provide evidence that marketing performance variables affect the competitive advantage.

Hypothesis testing in this study used two-step regression analysis. The value of the determination coefficient on the regression phase was obtained $\left(R^{2}\right)$ of 0.491 . The marketing performance variables that can be explained by product innovation and promotion is $49.1 \%$ and the remaining $50.1 \%$ is influenced by other factors. ANOVA test obtained result that is 31.928 with probability 0.000 . This means product innovation and promotion together have an influence on marketing performance.

Result of $t$ test to independent variable obtained probability value less than 0,05 , for product innovation variable $t$ value equal to 3,292 and probability value 0,002 . The results of this study provide empirical evidence that product innovation variables have an influence on marketing performance variables, proven. This is in accordance with the opinion said by Wulandari (2012) that if it can create product innovation will determine the performance of marketing in accordance with corporate goals. The second hypothesis of promotion has influence on marketing performance of SMEs weaving Troso Jepara with t test result that is 4,705 and probability value 0.000 . Promotion is one of the determinants of the success of marketing programs to provide information about the existence of product (Tjiptono, 2008). 
The second regression hypothesis test obtained the coefficient of determination $\mathrm{R}^{2}=0.445$. Variable of competitive advantage can be explained by marketing performance variable equal to $44,5 \%$ while the rest $55,5 \%$ influenced by other factor. ANOVA test obtained result that is 52.223 with probability 0.000 . Probability is less than 0.05 , it can be said that marketing performance has an effect on competitive advantage. In the calculation results of regression phase 2 obtained $\mathrm{Y} 2=0.673 \mathrm{Y} 1$. The performance of SME marketing Troso Jepara weaving has an influence on the competitive advantage with regression coefficient of 0.673 . On the hypothesis of marketing performance variables affect the benefits of competing with the results of $t$ test is 7.227 and the probability value 0.000 . Based on the results of these studies provide evidence that marketing performance variables affect the competitive advantage. The better of marketing performance, the higher of competitive advantage.

\section{CONCLUSIONS AND RECOMMENDATIONS}

\subsection{Conclusions}

Analysis conducted in strategy research create competitive advantage through marketing performance in SMEs weaving Troso Jepara yield three conclusion, that is:

a) The results of research using empirical data indicate that product innovation as measured by three indicators covering product line, new product, and artificial product have a positive and significant influence to marketing performance.

b) Results of research using empirical data indicate that promotion measured by six indicators including advertising, personal selling, sales promotion and publicity proved to have a positive and significant influence on marketing performance.

c) The results of research using empirical data indicate that marketing performance measured by three indicators that include profit targets, customer growth, and sales turnover proved to have a positive and significant impact on competitive advantage

\subsection{Managerial Implications}

Based on the results of research conducted on the variables of product innovation, promotion and marketing performance has been proven empirically are the variables that are important in creating competitive advantage in SMEs weaving Troso Jepara. So the managerial implications will be more focused on the three variables. The findings of this study indicate that in general the biggest influence in creating competitive advantage through marketing performance by increasing promotion. This can be seen from the causal relationships for promotion of marketing performance and to competitive advantage having a significance value of 0.000 at alpha 0.05 . So based on the findings of this study and based on 
the theories that have been developed it can be drawn some managerial implications with a priority scale on which items should take precedence as follows:

Table 13. Managerial Implications

\begin{tabular}{|c|c|c|}
\hline $\begin{array}{l}\text { Independent } \\
\text { Variabel }\end{array}$ & Indicator & Managerial Implications \\
\hline \multirow[t]{4}{*}{ Promotion } & Advertising & $\begin{array}{l}\text { Add catalogs to the showroom to let potential } \\
\text { buyers know the motives of Troso Jepara } \\
\text { weaving }\end{array}$ \\
\hline & $\begin{array}{l}\text { Personal } \\
\text { selling }\end{array}$ & $\begin{array}{l}\text { Salespeople should be trained to upgrade their } \\
\text { insights about Troso Jepara's weaving products } \\
\text { so that potential buyers believe and believe in } \\
\text { the product delivered by the salesperson }\end{array}$ \\
\hline & $\begin{array}{l}\text { Sales } \\
\text { Promotion }\end{array}$ & $\begin{array}{l}\text { Discount programs should be increased to } \\
\text { attract potential new buyers }\end{array}$ \\
\hline & Publicity & $\begin{array}{l}\text { SMEs Troso is expected to often conduct } \\
\text { exhibition events, fashion shows held outside } \\
\text { the city to be known by prospective buyers } \\
\text { nationwide }\end{array}$ \\
\hline \multirow[t]{3}{*}{$\begin{array}{l}\text { Product } \\
\text { Innovation }\end{array}$} & Product Line & $\begin{array}{l}\text { Troso weaving products are marketed in all } \\
\text { markets both domestically and abroad so as to } \\
\text { create competitive advantage }\end{array}$ \\
\hline & New Product & $\begin{array}{l}\text { Develop products by making designs that are } \\
\text { different from competitors }\end{array}$ \\
\hline & $\begin{array}{l}\text { Artificial } \\
\text { Products }\end{array}$ & $\begin{array}{l}\text { Making troso weaving that matches the target } \\
\text { market segment }\end{array}$ \\
\hline \multirow[t]{3}{*}{$\begin{array}{l}\text { Marketing } \\
\text { Performance }\end{array}$} & Profit target & $\begin{array}{l}\text { Maintain good relationships with customers so } \\
\text { that customers will return to purchase and profit } \\
\text { targets can be achieved from existing customers }\end{array}$ \\
\hline & $\begin{array}{l}\text { Customer } \\
\text { Growth }\end{array}$ & $\begin{array}{l}\text { Take advantage of existing technology to } \\
\text { increase the number of new consumers at the } \\
\text { national and international levels because most } \\
\text { of the world's society is much dependent on the } \\
\text { internet. }\end{array}$ \\
\hline & Sales turnover & $\begin{array}{l}\text { creativity and innovation must always be } \\
\text { updated to suit the existing social development } \\
\text { of the community so that it can increase sales } \\
\text { turnover }\end{array}$ \\
\hline
\end{tabular}

Research only uses variables of product innovation, promotion and marketing performance as factors that influence competitive advantage and that is 
why the three independent variables only have an influence on competitive advantage of $44.5 \%$. So need to look for other factors that theoretically affect the competitive advantage because management research is a multidimensional research. For future research it is advisable to add additional independent variables such as environmental adaptability, so as to explain high competitive advantages compared to other independent variables. Subsequent research should lead to research on the broader object of research, to get more general results on factors that influence marketing performance and can create competitive advantage.

\section{REFERENCES}

Fernando, Joyce, Raymond 2016. Analysis Quality Products, Promotion And Distribution to Performance Marketing In PT. Daya Adicipta Wisesa (Honda) Watutumou. Jurnal EMBA Vol.4 No.3 September 2016, Hal. 741750

Hair, J.F., et al. (2010). Multivariate data analysis. (7th edition). New Jersey: Pearson Education Inc.

Hubeis. 2012. Manajemen Kreatif dan Inovatif Dalam Bisnis. Jakarta: Inti Prima Promosindo

Ismawanti, Eryanafita. 2008. Analisis Faktor-Faktor yang Mempengaruhi Kinerja Pemasaran dengan Faktor Lingkungan sebagai Variabel Moderat (Studi Pada Industri Kerajinan Batik Di Pekalongan). Tesis. Program Studi Magister Manajemen Program Pasca Sarjana Universitas Diponegoro Semarang.

Kotler, 2008. Manajemen Pemasaran. Jakarta: Erlangga

Liu, Lie, dan Xue. 2011 Ownership, Strategic Orientation and Internationalization in Emerging Markets. Journal of World Business 46: 381-393

Martinez, J. A., Gamero, J., \& Tamayo, J. A. (2011). Analysis of innovation in SMEs using an innovative capability-based non-linear model: A study in the province of Seville (Spain). Journal of Technovation, 459-475.

Porter, Michael, E. 2007. Strategi Bersaing (Competitive Strategy). Karisma Publishing group. Tangerang

Retno, Henderi, Hidayat (2010). Peran Orientasi Pasar, Program Promosi Dan Inovasi Dalam Menentukan Kinerja Pemasaran Jasa. Jurnal Binus Business Review Vol.1 No.2 November 2010: 378-387 
Sitohang, Sonang. 2010. Pengaruh Kualitas Sumber Daya Manusia Terhadap Kinerja Pengrajin Sentra Industri Kecil Tenun Ikat. Ekuitas. Jurnal Ekonomi dan Keuangan 14(1): 57-81.

Sugara Mursid, Suharno Suharno, Wahyu Budi Priatna. (2018). The Effect of Social Capital on the Innovation Performance of the Small-Middle Scaled Enterprises of Agribusiness in Bogor Regency. Indonesian Journal of Business and Entrepreneurship Vol. 4 No. 1:22-36

Suhendro, G. (2010). Analisis Pengaruh Inovasi Produk Melalui Kinerja Pemasaran Untuk Mencapai Keunggulan Bersaing Berkelanjutan. Jurnal Fakultas Magister Manajemen, UNDIP, Semarang

Sukarno, 2011. Meningkatkan Kinerja Pemasaran UMKM Melalui Peran Lingkungan, Inovasi Produk dan Kreativitas Strategi Pemasaran. Jurnal Ekuitas Vol 15 No. 3 Nopember 2011.

Suriatna, Danny, dan R.R Retno Ardianti, 2013. Analisa Modal Sosial dan Inovasi Produk pada Pengusaha Mikro dan Kecil di Jawa Timur. Jurnal Agora, Vol.1, No. 3

Sya'roni, J Sudirham. 2012. Kreativitas dan Inovasi Penentu Kompetensi Pelaku Usaha Kecil. Jurnal Manajemen Teknologi

Tjiptono, Fandy. 2008. Strategi Pemasaran. Edisi 1. Cetakan keenam. Yogyakarta : Andi Offset

Wartini, Sri. 2013. Analisis Pengaruh Promosi, Harga dan Keunggulan Produk terhadap Kinerja Pemasaran. Jurnal Prestari Volume 11 No.1

Widjajanti, Kesi, dan Aprih Santoso, 2012, Pemodelan Kemitraan yang Berorientasi Pasar dalam Mendukung Peningkatan Kinerja UKM Industri Mebel. Jurnal Fakultas Ekonomi Manajemen Universitas Semarang

Wulandari, Agesti, 2012. Pengaruh Orientasi Pelanggan, Orientasi Pesaing dan Inovasi Produk terhadap Kinerja Pemasaran. Management Analysis Journal 